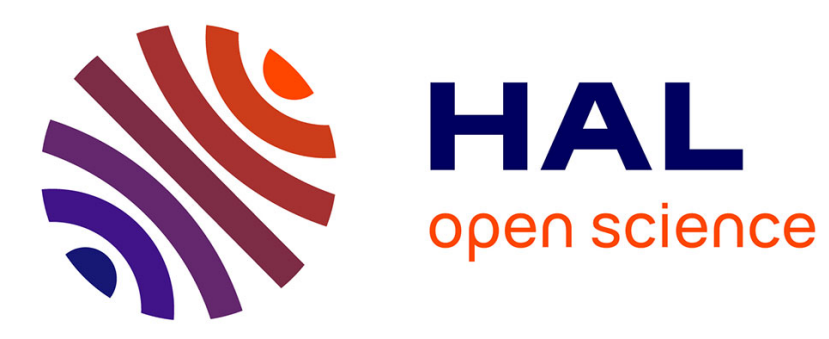

\title{
Seaweed and Sea Anemones proteins as a source of new pharmaceutical active principles
}

\author{
Erwann Loret, N Flórez-Fernández, M D Torres, A Grenha, H Domínguez
}

\section{To cite this version:}

Erwann Loret, N Flórez-Fernández, M D Torres, A Grenha, H Domínguez. Seaweed and Sea Anemones proteins as a source of new pharmaceutical active principles. Marine Niche: Applications in Pharmaceutical Sciences (pp.203-219), 2021, 10.1007/978-981-15-5017-1_11 . hal-03432718

\section{HAL Id: hal-03432718 \\ https://hal.science/hal-03432718}

Submitted on 17 Nov 2021

HAL is a multi-disciplinary open access archive for the deposit and dissemination of scientific research documents, whether they are published or not. The documents may come from teaching and research institutions in France or abroad, or from public or private research centers.
L'archive ouverte pluridisciplinaire HAL, est destinée au dépôt et à la diffusion de documents scientifiques de niveau recherche, publiés ou non, émanant des établissements d'enseignement et de recherche français ou étrangers, des laboratoires publics ou privés. 


\title{
Seaweed and Sea Anemones proteins as a source of new pharmaceutical active principles
}

\author{
N. Flórez-Fernández ${ }^{1,2}$, M.D. Torres ${ }^{1}$, A. Grenha ${ }^{2}$, E. P. Loret ${ }^{3}$, H. Domínguez ${ }^{1} *$ \\ ${ }^{1}$ Chemical Engineering Department. Faculty of Science. University Vigo, Spain \\ ${ }^{2}$ Centre for Marine Sciences, University of Algarve, Faro, 8005-139, Portugal \\ ${ }^{3}$ Institut Méditerranéen de Biodiversité et d'Ecologie Aix Marseille University/ \\ Université d'Avignon/Institut pour la Recherche et le Développement/Centre National \\ de la Recherche Scientifique, France
}

Ref : Flórez-Fernández N., Torres M. D., Braz L., Grenha A., Loret E. P., Domínguez H.. Seaweed and Sea Anemones Proteins as a Source of New Pharmaceutical Active Principles In book: Marine Niche: Applications in Pharmaceutical Sciences (pp.203-219) November 2020 DOI:10.1007/978$\underline{981-15-5017-1 \_11}$

\begin{abstract}
Among marine sources, seaweeds and sea anemones are highly attractive for their diversity and complex composition, the major components being polysaccharides, proteins, pigments, phenolic compounds, vitamins and minerals. Seaweeds and sea anemones could be a source of different proteins and peptides with unique structures with interesting biological properties, such as antitumoral, antimicrobial, antiinflammatory, antidiabetic, antioxidant, among others. This chapter presents an overview on the marine algal and anemone bioactive proteins and peptides, their extraction and the development of novel carrier systems with potential interest for pharmaceutical applications.
\end{abstract}

Key words: seaweeds, anemones, proteins, peptides, bioactives, encapsulation

\section{Introduction}

The biodiversity of marine environment is a rich source of chemical structures with interesting biological properties for a potential development of alternative therapeutic products. Abundant research studies on drug discovery from natural sources explored the marine ecosystems for novel bioactive compounds. Particular attention was on 
sedentary organisms, producing a variety of compounds with protecting and defending activities.

Seaweeds show a complex composition, containing mainly polysaccharides, proteins, lipids and minerals. Although their commercial utilization is mainly based on the extraction of the saccharidic fraction for gelling purposes, the protein fraction also represents a sustainable source for the production of peptide-based drugs and functional foods.

Sea anemones have an arsenal of molecules that helps them to capture prey or defend from predators. Their venoms are complex mixtures of peptides and small proteins that were explored for the development of new active principles against cancer and neurodegenerative diseases, based on their actions as ionic channel blockers, neurotoxins, protease inhibitors, and pore-forming toxins (Álvarez et al., 2009, Dutertre and Lewis, 2010, Thangaraj and Bragadeeswaran, 2012; Mac Rander et al., 2016a and b; Logashina et al 2017, Loret et al., 2018).

This chapter presents an overview of the potential of proteins from anemones and seaweeds as a natural source of active compounds with potent pharmacological properties, the extraction technologies and their potential for developing novel products.

\section{Properties}

\section{Seaweed protein properties}

In the past decades, novel compounds with antiobesity activity (Jin et al., 2018).

Seaweeds are promising natural sources based on their wide distribution, rapid growth rate, high content of proteins, up to $30-40 \%$ of the dry weight, and diverse profile of bioactive compounds, such as phycobiliproteins, phycolectins and mycosporine-like amino acids (Cian et al., 2015; Admassu et al., 2018).

Bioactive peptides, usually 2 to 20 amino acids, show activity when released by protein degradation by endogenous and exogenous enzymatic action, processing or gastrointestinal digestion show a variety of therapeutic actions, such as regulation of mucosal barrier function, prevention of hypertension, enhancing mineral absorption, lowering cholesterol, and showing antihypertensive, anti-inflammatory, immunomodulatory, antimicrobial, antithrombotic, antioxidant, antiobesity and 
antidiabetic activities (Qu et al., 2010; Holdt and Kraan, 2011; Cian et al., 2015; Hayes and Tiwari, 2015; Admassu et al., 2018). Short chain peptides, often carrying polar amino acid residues like proline and with hydrophobic amino acids at the C-terminal tripeptide sequence have the ability to inhibit Angiotensin-I-converting enzyme (ACE), which is a major therapeutic approach in the prevention of hypertension. Antihypertensive peptides are good therapeutic approaches in the management of hypertension (Wijesekara and Kim, 2010) without the side effects of other pharmacological drugs (Admassu et al., 2018). Peptides with 2 to 6 amino acids are absorbed more readily than proteins and free amino acids, although it has also been suggested that also larger peptides (10 to 50 amino acids) can cross intestinal barrier and show biological actions at the tissue level. The influence of the structure on the antioxidant properties has been studied by a number of groups the most active peptides were those with low molecular weights (Wang et al., 2010; Cian et al., 2015).

Mycosporine-like amino acids (MAAs) are secondary metabolites of low molecular weight $(<400 \mathrm{Da})$ with ultraviolet-absorbing $(\lambda \max =309-360 \mathrm{~nm})$ protection $(C i a n$ et al., 2015; Wijesekara \& Kim, 2015). They have a role in UV-protection, and have antioxidant activity capable of protecting against the cellular damage that high levels of reactive oxygen species (ROS).

Lectins are carbohydrate binding proteins responsible for lectin involvement in numerous biological processes such as host-pathogen interactions, cell-cell communication, induction of apoptosis, cancer metastasis and cell differentiation (Cian et al., 2015).

Phycobiliproteins, accounting for half of the total protein content of red seaweeds, are fluorescent proteins covalently linked to tetrapyrrole groups, and found in phycobilisomes. The major are phycoerythrin, phycocyanin, allophycocyanin, and phycoerythrocyanin, and they have applications based on their color and their biological properties, including antimicrobial, anti-inflammatory, neuroprotective, hepatoprotective, immunomodulating and anticarcinogenic activities (Aryee et al., 2018; Mittal et al., 2018). 


\section{Sea anemones proteins and cancer treatments}

Sea anemones are the best known source of low molecular weight $(<5000 \mathrm{Da})$ active principles. They all have three disulfide bridges and share sequence homologies but point mutations can totally change their structures and their pharmacological properties. A wide variety of compounds with different activities was therefore identified, such as neurotoxicity, cytolytic (Oliveira et al., 2006; Pedrera et al., 2014), haemolytic, analgesic, anti-inflammatory (Oliveira et al., 2006; Thangaraj and Bragadeeswaran, 2012; Celedón et al., 2008; Stabili et al., 2015), anti-hyperglycemic and anti-diabetic (Lauritano 2016). Although most of these proteins were found in tentacles, the mucus appears also a promising alternative source of antimicrobial lysozyme-like antibacterial agents, which have different modes of action regarding conventional antibiotics (Subramanian et al., 2011; Stabili et al., 2015). Some of these proteins, such as sticholysins are exclusively found in sea anemones (Pedrera et al., 2014), these cysteine-less proteins, with molecular weights around $20 \mathrm{kDa}$, high isoelectric points (>9.5), are water soluble and can interact with membranes and form a stable membrane pore (Álvarez et al., 2009).

Mycosporine-like amino acids are also found in sea anemones, among them shinorine, porphyra-334, mycosporine-2 glycine, palythine-serine sulphate, stylophorasulphate, palythine, asterina-330, palythinol, mycosporine-taurine, and mycosporinesulphate ester. The highest concentration is often found in areas exposed to sunlight, they can also be of dietary origin, present in food or resulting from transformations of dietary MAAs by action of specific anemone enzymes or bacteria harbored in the anemones coelenteron or ectodermal tissue (Arbeloa et al., 2010).

Regarding cancer research, sea anemone proteins showed recently interesting development (Loret et al., 2018). Cancer treatments are mainly based on anti-mitotic compounds that have side effects because they block both the division of cancer cells and healthy cells. Cancer cells need to be vascularized by endothelial cells to grow as a tumor and then to spread to metastasize and kill patients. Vascularization is called angiogenesis and it was proposed almost 50 years ago to block angiogenesis to fight against cancer because angiogenesis is no longer important after embryogenesis (Folkman 1971). Amazingly there are very few antiangiogenic compounds compared to antimitotic compounds and it is only since a decade that antiangiogenic compounds began to be tested in clinical trials. Moreover the antiangiogenic compounds showed a 
limited efficacy because they all binds on the Vascular Endothelial Growth Factor (VEGF) or the VEGF receptor and tumor cells can trigger different biological ways to have angiogenesis (Carmeliet \& Jain 2011). Among antiangiogenic compounds binding on VEGF, the most used in clinical trial is the Bevacizumab (known as Avastin), which is a monoclonal antibody. Bevacizumab is costly due to its size and difficulties to have a germ free production as recombinant protein. Furthermore resistance to Bevacizumab is observed due to the upregulation of other redundant angiogenic factors different from VEGF (Kong 2017). The other compounds binding on VEGF are also monoclonal antibodies or Fab fragments. Compounds binding on VEGF receptors that are not proteins have toxic effects that limit their use (Chu 2007).

There is therefore a need to have compounds blocking angiogenesis that do not bind on VEGF or VEGF receptor, easy to produce and with no long term toxicity. Short size synthetic proteins (less than 50 residues) are suitable compounds for this goal. Anemonia viviridis (called also Anemonia sulcata) have been widely studied and proved to be a remarkable source of low molecular proteins with different pharmacological binding sites on ionic channel receptors (Diochot et al., 2003). Seven short size proteins (42 to 49 residues) binding on ionic channels were purified and characterized from Anemonia viviridis. Among them, BDS 1 is a blood depressing protein of 43 residues (4708 Da) binding on a specific potassium channel and is commercialized as a synthetic protein to treat heart disease (Diochot, 1998). The NMR structure of BDS 1 revealed that the main secondary structure is a triple-stranded antiparallel beta-sheet and no alpha helix (Driscoll, 1989). A partially purified extracts of Anemonia viviridis was reported to affect the growth and viability of selected tumor cell lines (Bulati 2016).

Synthetic proteins $<50$ residues are now affordable and have the great advantage to made possible a sterile production, which is not the case for monoclonal antibodies such as Avastin that required a biological production. The high cost of Avastin is not related to the production as recombinant protein but to the purification process to have a germ free pharmaceutical production. A very low molecular weight compounds $(<1000 \mathrm{Da})$ would be certainly less expensive to produce than a synthetic protein. However a new chemical family of active principle requires now very expensive toxicological studies to have a Drug Master File suitable for clinical studies. Moreover, it turns out that actual preclinical toxicity studies required for clinical studies are not sufficient to guaranty an absence of long term toxicities. This long term toxicities are often due to accumulation in tissues of chemical compounds that cannot be 
or are insufficiently degraded. Therefore a synthetic protein (with a molecular weight $<$ $5000 \mathrm{Da}$ ) represents a good compromise between coast of production and safety issues and sea anemones are a rich source of small proteins that could be potential active principles.

\section{Processing technologies}

\section{Seaweed}

Among seaweeds, the highest protein levels, up to $50 \%$ of dry matter has been reported for red algae, compared to green (up to $25 \%$ ), and brown (under $15 \%$ ) (Cian et al., 2015). Most seaweeds contain all the essential amino acids, show high contenty of aspartic and glutamic acid, and lower of threonine, lysine, tryptophan, cysteine, methionine and histidine. The carbohydrate fraction is the most abundant and its composition depends on the type of seaweed, other important constituents are minerals, whereas the lipid fraction is low.

Seaweeds contain a highly structural complex algal cell wall, which makes difficult the efficient extraction and digestibility of protein fractions (Admassu et al., 2018). The classic extraction methods are limited by the high viscosity and anionic bonding of the cell-wall polysaccharides and glycoproteins. Grinding in liquid nitrogen was proposed, but this approach is costly at industrial scale and does not provide an efficient degradation of cell wall. The development of novel extraction methods is a key to facilitate the disruption of the cell wall, facilitate access to the seaweed bioactive peptides maintaining high yields and optimal functional properties. Physical, chemical and enzymatic treatments have been proposed to obtain high protein yields. Among the most efficient are those based on the intensification of the extraction process with ultrasound or pulsed electric fields, as well as the use of pressurized solvent extraction and enzyme-assisted extraction (Wijesinghe and Jeon, 2012; Flórez-Fernández et al., 2017; Admassu et al., 2018).

Ultrasound assisted processes can provide higher protein extraction yields in shorted processing times than conventional extraction with acid or with alkaline media (Kadam et al., 2016; Mittal et al. (2017)). Temperature requires adequate to avoid undesirable thermal and chemical effects adequate selection of frequency is recommended, and the 
use of different alternating frequencies could enhance protein extraction yields $(\mathrm{Qu}$ et al., 2013a).

The type of enzyme influences the extraction yield, and also the composition and properties of the extracts. The use of carbohydrases alone, including those developed for terrestrial biomass, such as $\beta$-glucanases, cellulases, xylanases, could enhance the protein extraction yield (Fleurence, 1999; Wang et al., 2010) or would require the combined use with other polysaccharidase or with other specific enzymes, such as carrageenase or agarase (Fleurence et al., 1995; Denis et al., 2009; Mittal et al., 2018). Among the operational variables affecting he process are $\mathrm{pH}$ and temperature, which should be optimal for both enzyme action and protein recovery, liquid to solid ratio, time and the enzyme to substrate ratio, which should be carefully optimized, since the enzyme costs would be one of the major limitations of this technique. Enzyme assisted extraction can also be combined with other technologies, such as ultrasound for the extraction of R-phycoerythrin (Le Guillard et al., 2015).

Pressurized hot water extraction of protein was proposed at $120-270{ }^{\circ} \mathrm{C}$ to enhance the yields and productivity in an environmentally friendly operatrion (Gereniu et al., 2017, Pangestuti et al., 2019).

After the extraction process, additional hydrolysis stages are required to cause the release of functional peptides. One of the preferred method is enzymatic hydrolysis with a single activity or combinations of them, since it can be performed under milder conditions than chemical and physical treatments (Wang et al., 2010; Samarakoon and Jeon 2012). Admassu et al. (2018) compiled the enzymes, including pepsin, trypsin, papain, chymotrypsin, alcalase, fungal proteases have been used more commonly for hydrolysis of seaweed proteins in producing ACE inhibitory and antioxidant peptides.

The released bioactive peptides are then concentrated and fractionated. Qu and others (2015) have reported a continuous enzymatic bioreactor with membrane separation in a multistep recycling system and fractionate the hydrolysates according to ranges of their molecular weight. Purification of this protein is performed by different techniques such as ammonium sulfate precipitation and chromatographic techniques (ion exchange, gel filtration, etc.). Usually a stage with ultrafiltration membranes is proposed for targeting a desirable molecular weigth range, and ion exchange, affinity chromatography and high performance liquid chromatography are used for purification and enrichment of bioactive components (Harnedy et al., 2017; Cheung and others 2015). Adequate 
definition of downstream stages is required to develop cost effective processing (Hayes and Tiwari, 2015).
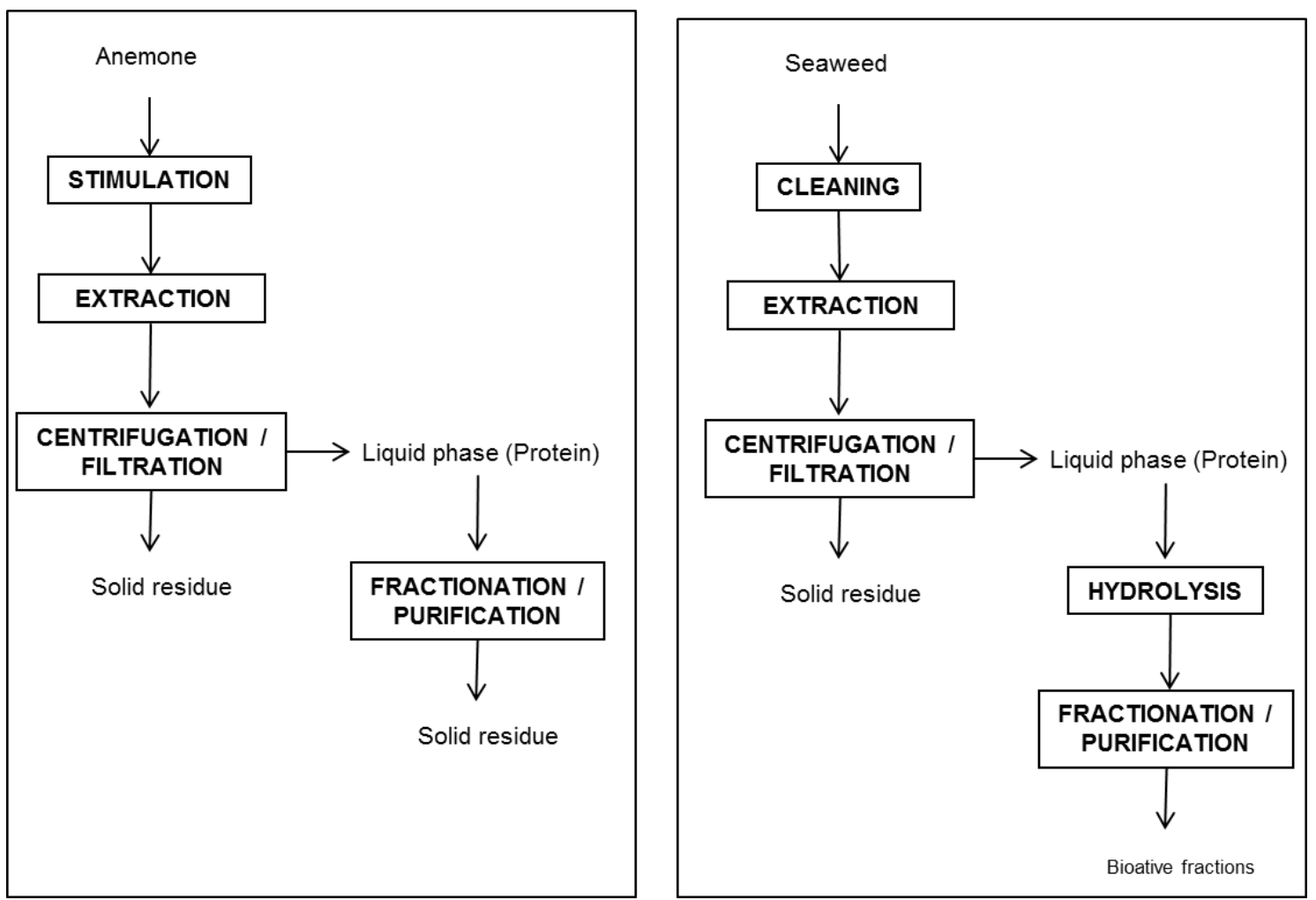

Figure 1. Simplified flow diagram of the processes for the extraction of bioactive protein fractions from a) amemones abd b) seaweeds.

\section{Anemone}

In see anemones the venom system is decentralized in all parts of the animal body and is delivered by characteristic stinging organelles or nematocysts, located on body surfaces and in high concentration on tentacles, with functions related to defense against predators and prey captures. These organs possess a high concentration of a diverse range of sizes (12-200 kDa) and protein active principles (Oliveira et al., 2006; Subramanian et al., 2011; Stability et al., 2015), many of them could not be identified in other animals suggesting that they might be the products of taxonomically restricted genes (Moran et al., 2013).

The mucus produced by the sea anemones is composed in more than $95 \%$ by water and the major components of the dry fraction are minerals, more than $60 \%$, protein up to 25\%, carbohydrates 5-10\% and less than 1\% lipid (Stabili et al., 2015). 
During stress condition the nematocysts can be released from the tentacles. The process can be repeated and the collected nematocysts containing toxins can be filtered, centrifugated and the supernantant collected for lyophilisation (Subramanian et al., 2011).

An easy and ecological method to extract bioactive compounds from sea anemones, consisted on maintaining and feeding the animals in aquarium, facilitating an increased milking frequency through electrical stimulation, avoiding to kill them and possibiliting to return to the sea (Oliveira et al., 2006). Most authors have proposed aqueous, methanol, dichloromethane and ethanol extracts (Subramanian et al., 2011; Thangaraj and Bragadeeswaran, 2012). The crude extracts have to be filtered, evaporated and lyophilized.

Fractionation in C18 columns was proposed for partial purification of methanol extracts (Arbeloa et al., 2010), or for semipreparative chromatography of the selected fractions from Sephadex G-50 gel filtration (Oliveira et al., 2006). Membrane separation was also proposed for extract purification of anemone mucus extract components before chromatographic techniques (Stabili et al., 2015).

\section{Conclusions and future trends}

The molecules synthesized by sedentary marine microorganisms could have potential for novel products with pharmacological applications. Sea anemones contain a variety of bioactive compounds including some toxins, which could have potential for the production of bioactive compounds of high pharmaceutical and biotechnological interest, i.e., antihypertensive peptides and antimicrobial molecules or immunotoxins against tumoral cells. Further advances and improvement in extraction and isolation of peptides from seaweed and anemones are expected to comply with the growing demand for novel efficient side effects free natural derived drugs, as well as the development of cleaner efficient processes. 


\section{References:}

Admassu, H., Gasmalla, M.A.A., Yang, R., Zhao, W. Bioactive Peptides Derived from Seaweed Protein and Their Health Benefits: Antihypertensive, Antioxidant, and Antidiabetic Properties. J. Food Sci., 83, 1, 2018, 6-16

Álvarez, C., Mancheño, J.M., Martínez, D., Tejuca, M., Pazos, F., Lanio, M.E. Sticholysins, two pore-forming toxins produced by the Caribbean Sea anemone Stichodactyla helianthus: Their interaction with membranes. Toxicon, $54,8,2009,1135-1147$.

Arbeloa, E.M., Carignan, M.O., Acuña, F.H., Churio, M.S., Carreto, J.I. Mycosporine-like amino acid content in the sea anemones Aulactinia marplatensis, Oulactis muscosa and Anthothoe chilensis. Comp. Biochem. Physiol.- B Biochem. Molecular Biol., 156, 3, 2010, 216-221.

Aryee, A.N., Agyei, D., Akanbi, T.O. Recovery and utilization of seaweed pigments in food processing. Curr. Op. Food Sci., 19, 2018, 113-119.

Ben-Gharbia H, Yahia OK, Amzil Z, Chomérat N, Abadie E, Masseret E, Sibat M, Zmerli Triki H, Nouri H, Laabir M. Toxicity and Growth Assessments of Three Thermophilic Benthic Dinoflagellates (Ostreopsis cf. ovata, Prorocentrum lima and Coolia monotis) Developing in the Southern Mediterranean Basin. Active principles (Basel). 2016 Oct 15;8(10).

Bulati, M., Longo, A.,Masullo, T.,Vlah, S., Bennici, C.,Bonura, A., Salamone, M., Tagliavia, M., Nicosia, A., Mazzola, S., Colombo, P., Cuttitta, A.Partially Purified Extracts of Sea Anemone Anemonia viridis Affect the Growth and Viability of Selected Tumour Cell Lines. BioMed Res. Int., 2016, Article number 3849897

Cachet N, Genta-Jouve G, Ivanisevic J, Chevaldonné P, Sinniger F, Culioli G, Pérez T, Thomas OP. (2015). Metabolomic profiling reveals deep chemical divergence between two morphotypes of the zoanthid Parazoanthus axinellae. Sci Rep. ;5:8282.

Campbell, GR, \& Loret E., P. (2009) What does the structure-function relationship of the HIV-1 Tat protein teach us about developing an AIDS vaccine? Retrovirology 6, 50-63. 
Celedón, G., González, G., Barrientos, D., Pino, J., Venegas, F., Lissi, E.A., Soto, C., Martinez, D., Alvarez, C.d, Lanio, M.E. Stycholysin II, a cytolysin from the sea anemone Stichodactyla helianthus promotes higher hemolysis in aged red blood cells. Toxicon, 51, 8, 2008, 1383-1390

Cian, R.E., Drago, S.R., De Medina, F.S., Martínez-Augustin, O. Proteins and carbohydrates from red seaweeds: Evidence for beneficial effects on gut function and microbiota. Mar. Drugs, 13, 8, 2015, 5358-5383.

Denis, C., Le Jeune, H. Gaudin, P. Fleurence, J. An evaluation of methods for quantifying the enzymatic degradation of red seaweed Grateloupia turuturu. J. Appl. Phycol., 21 (2009), pp. 153-159

Diochot S, Loret E, Bruhn T, Beress L, Lazdunski M. (2003) APETx1, a new toxin from the sea anemone Anthopleura elegantissima, blocks voltagegated human ether-a-go-go-related gene potassium channels. Mol Pharmacol. 64, 59-69.

Dutertre, S., Lewis, R.J Use of venom peptides to probe ion channel structure and function. J. Biol. Chem., 285, 18, 2010, 13315-13320.

El Kateb A, Stalder C, Neururer C, Pisapia C, Spezzaferri S. (2016) Correlation between pollution and decline of Scleractinian Cladocora caespitosa (Linnaeus, 1758) in the Gulf of Gabes. Heliyon. 16;2(11):e00195

Fleurence, J.,Massiani, L.,Guyader, O.,Mabeau, S.Use of enzymatic cell wall degradation for improvement of protein extraction from Chondrus crispus, Gracilaria verrucosa and Palmaria palmate. J. Appl. Phycol., 7, 4, 1995, 393397.

Flórez-Fernández, N., Casas, M. P., González-Muñoz, M.J., Domínguez, H. 2017. Combination of water-based extraction technologies. In Water extraction of bioactive compounds. Domínguez, H. and González-Muñoz, M.J. eds. Elsevier, Kidlington, Oxford United Kingdom.

Folkman J, Merler E, Abernathy C, Williams G. Isolation of a tumor factor responsible for angiogenesis. J Exp Med. 1971 Feb 1;133(2):275-88.

Gereniu, C.R.N., Saravana, P.S., Getachew, A.T., Chun, B.-S. Characteristics of functional materials recovered from Solomon 
Islands red seaweed (Kappaphycus alvarezii) using pressurized hot water extraction. J. Appl. Phycol., 29, 3, 2017, 1609-1621.

Harnedy, P.A., O'Keeffe, M.B., FitzGerald, R.J. Fractionation and identification of antioxidant peptides from an enzymatically hydrolysed Palmaria palmata protein isolate. Food Res. Int., 100, 2017, 416-422.

Hayes, M., Tiwari, B.K. Bioactive carbohydrates and peptides in foods: An overview of sources, downstream processing steps and associated bioactivities. Int. J. Molec. Sci.,16, 9, 2015, 22485-22508.

Jin, Q., Yu, H., Li, P. The evaluation and utilization of marine-derived bioactive compounds with anti-obesity effect. Curr. Med. Chem., 25, 7, 2018, 861-878.

Kallech-Ziri, O., Luis., J., Faljoun, Z., Sabatier, J.M., Lehmann, M., El Ayeb, M., Marrakchi, N., Loret, E.P. (2010) Structure Function relationships of KTS disintegrins and design of Antiangiogenic Drugs. Letters in Drug Design \& Discovery 5, 36-40.

Kong DH, Kim MR, Jang JH, Na HJ, Lee S. A Review of Anti-Angiogenic Targets for Monoclonal Antibody Cancer Therapy. Int J Mol Sci. 2017 Aug 17;18(8). pii: E1786

Le Guillard, C., Dumay, J., Donnay-Moreno, C., Bruzac, S., Ragon, J.-Y., Fleurence, J., Bergé, J.-P. Ultrasound-assisted extraction of Rphycoerythrin from Grateloupia turuturu with and without enzyme addition. Algal Res., 12, 2015, 522-528.

Logashina YA, Mosharova IV, Korolkova YV, Shelukhina IV, Dyachenko IA, Palikov VA, Palikova YA, Murashev AN, Kozlov SA, Stensvåg K, Andreev YA. Peptide from Sea Anemone Metridium senile Affects Transient Receptor Potential Ankyrin-repeat 1 (TRPA1) Function and Produces Analgesic Effect. (2017) J Biol Chem. 2017 292(7):2992-3004.

Loret, E. P. \& Hammock, B. (2001) Structure and Neurotoxicity of venom. in The Biology of Scorpion. Eds. Brownell \& Polis, Oxford University press, pp 204-234. 
Loret, E., Menendez, R., Mansuelle, P., Sampieri, F., \& Rochat, H. (1994) Positvely Charged Amino Acid Residues Located Similarly in Sea Anemone and Scorpion Active principles. J. Biol. Chem. 269, 16785-16788.

Macrander J, Broe M, and Daly M. (2016) Tissue-Specific Venom Composition and Differential Gene Expression in Sea Anemones. Genome Biol Evol.8, 2358-2375

Macrander J, Daly M. (2016) Evolution of the Cytolytic Pore-Forming Proteins (Actinoporins) in Sea Anemones Active principles (Basel). 2016 Dec 8;8(12). pii: E368

Mittal, R., Raghavarao, K.S.M.S.Extraction of R-Phycoerythrin from marine macro-algae, Gelidium pusillum, employing consortia of enzymes. Algal Res., 34, 2018, 1-11.

Mittal, R., Tavanandi, H.A., Mantri, V.A., Raghavarao, K.S.M.S Ultrasound assisted methods for enhanced extraction of phycobiliproteins from marine macro-algae, Gelidium pusillum. Ultrasonics Sonochem., 38, 2017, 92103.

Moran, Y., Praher, D., Schlesinger, A., Ayalon, A., Tal, Y., Technau, U. Analysis of Soluble Protein Contents from the Nematocysts of a Model Sea Anemone Sheds Light on Venom Evolution. Marine Biotechnol., 15, 3, 2013, 329-339.

Oliveira, J.S., Zaharenko, A.J., Ferreira Jr., W.A., Konno, K., Shida, C.S., Richardson, M., Lúcio, A.D., Beirão, P.S.L., de Freitas, J.C. BcIV, a new paralyzing peptide obtained from the venom of the sea anemone Bunodosoma caissarum. A comparison with the $\mathrm{Na}+$ channel toxin BcIII. Biochimica et Biophysica Acta - Proteins and Proteomics, 1764, 10, 2006, 1592-1600.

Otero, M., Cebrian, E., Francour, P., Galil, B., Savini, D. (2013). Surveillance des espèces envahissantes marines dans les aires marines protégées (AMP) méditerranéennes : guide pratique et stratégique à l'attention des gestionnaires. Revue de l'UICN. 136 pages.

Pangestuti, R., Getachew, A.T., Siahaan, E.A., Chun, B.-S. Characterization of functional materials derived from tropical red seaweed Hypnea musciformis produced by subcritical water extraction systems. J. Appl. Phycol., 2019 
Pedrera, L, Fanani, M.L., Ros, U., Lanio, M.E., Maggio, B.,Álvarez, C. Sticholysin I-membrane interaction: An interplay between the presence of sphingomyelin and membrane fluidity. Biochimica et Biophysica Acta Biomembranes, 1838, 7, 2014, 1752-1759.

Rodolfo-Metalpa R1, Richard C, Allemand D, Ferrier-Pagès C. (2006) Growth and photosynthesis of two Mediterranean corals, Cladocora caespitosa and Oculina patagonica, under normal and elevated temperatures. J Exp Biol. 209: 4546-4556.

Stabili L, Schirosi R, Parisi MG, Piraino S, Cammarata M (2015). The Mucus of Actinia equine (Anthozoa, Cnidaria): An Unexplored Resource for Potential Applicative Purposes. Mar Drugs.13, 5276-5296.

Subramanian, B., Sangappellai, T., Rajak, R.C., Diraviam, B. Pharmacological and biomedical properties of sea anemones Paracondactylis indicus, Paracondactylis sinensis, Heteractis magnifica and Stichodactyla haddoni from East coast of India. Asian Pacific J. Tropical Med., 4, 9, 2011, $722-726$.

Thangaraj, S., Bragadeeswaran, S. Assessment of biomedical and pharmacological activities of sea anemones Stichodactyla mertensii and Stichodactyla gigantea from Gulf of Mannar Biosphere Reserve, southeast coast of India. J. Venomous Animals and Toxins Including Tropical Diseases, 18, 1, 2012, 53-61.

Wang, T., Jónsdóttir, R., Kristinsson, H.G., Hreggvidsson, G. O. Jónsson, J. Ó., Thorkelsson, G., Ólafsdóttire, G.Enzyme-enhanced extraction of antioxidant ingredients from red algae Palmaria palmata. LWT - Food Sci. Technol.,43, 9, 2010, 1387-1393.

Wijesekara, I., Kim, S.-K. Angiotensin-I-converting enzyme (ACE) inhibitors from marine resources: Prospects in the pharmaceutical industry. Mar. Drugs, 8, 4, 2010, 1080-1093. 